JAMP: Jurnal Adminitrasi dan Manajemen Pendidikan

Volume 3 Nomor 1 Maret 2020, Hal : 11-18

Tersedia Online di http://journal2.um.ac.id/index.php/jamp/

ISSN 2615-8574 (online)

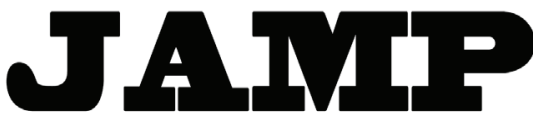

JURNAL ADMINISTRASI DAN MANAJEMEN PENDIDIKAN

\title{
HUBUNGAN KEIKUTSERTAAN EKSTRAKURIKULER PRAMUKA DENGAN TINGKAT KEDISIPLINAN SISWA
}

\author{
Taufik Aziz Jatmiko \\ H. A. Supriyanto \\ Ahmad Nurabadi \\ Universitas Negeri Malang, Jl. Semarang 5 Malang 65145 \\ Email: topek.jatmiko@gmail.com,
}

\begin{abstract}
Research aims to describe the scout extracurricular participation, describing the level of discipline of students in Public Vocational High School Malang City. This research uses a quantitative approach to the type of descriptive-correlational quantitative research. Collecting data this study used a questionnaire or a questionnaire distributed to students as many as 364 students, which has been divided into 12 Vocational High School in Malang. The results showed that the level of participation of extracurricular scouts were getting results, and the results of the level of discipline students get the results being. There is a relationship between extracurricular participation scout with the level of discipline of students in Public Vocational High School Malang City. Relationships resulting from extracurricular participation variables scout with the level of discipline of students categorized as moderate.
\end{abstract}

Keyword: extracurricular scouts, and the level of student discipline

\begin{abstract}
Abstrak: Penelitian ini bertujuan untuk mendiskripsikan keikutsertaan ekstrakurikuler pramuka, mendiskripsikan tingkat kedisiplinan siswa di SMK Negeri se-Kota Malang. Penelitian ini menggunakan pendekatan kuantitatif dengan jenis penelitian kuantitaif deskriptif-korelasional. Pengambilan data penelitian ini menggunakan angket atau kuesioner yang dibagikan kepada siswa sebanyak 364 siswa, yang sudah dibagi kedalam 12 SMK Negeri di Kota Malang. Hasil penelitian menunjukkan bahwa tingkat keikutsertaan ekstrakurikuler pramuka mendapatkan hasil sedang, dan hasil tingkat kedisiplinan siswa mendapatkan hasil sedang. Ada hubungan antara keikutsertaan ekstrakurikuler pramuka dengan tingkat kedisiplinan siswa di SMK Negeri se-Kota Malang. Hubungan yang dihasilkan dari variabel keikutsertaan ekstrakurikuler pramuka dengan tingkat kedisiplinan siswa berkategori sedang.
\end{abstract}

Kata Kunci: ekstrakurikuler pramuka, dan tingkat kedisiplinan siswa

Ekstrakurikuler pramuka adalah sebuah kegiatan ekstrkurikuler yang sekarang diwajibkan dalam sekolah-sekolah sebagai proses untuk membentuk karakter serta membentuk perilaku disiplin siswa yang baik disekolah maupun diluar sekolah. Kegiatan ekstrakurikuler pramuka disekolah saat ini dalam penerapanya sudah mengacu pada kurikulum 2013, sehingga satu minggu sekali disekolah ada ekstrakurikuler pramuka. Penerapan pramuka disekolah tidak selalu berjalan dengan mulus, banyak siswa yang kurang disiplin untuk mengikuti ekstrakurikuler pramuka disekolah. Selain itu proses kegiatan pembelajran disekolah sekarang ini, banyak sekali yang kita dapat temui mengenai kedisiplinan siswa yang semakin berkurang. Maka dari itu dalam kurikulum baru yang ada disekolah sudah harus mewajibkan ekstrakurikuler pramuka sebagai pembentuk karakter kedisiplinan yang harus diikuti oleh siswa selain itu juga karakter yang baik juga dapat mendukung dan membentuk cara berfikir siswa yang baik agar prestasi belajr siswa di sekolah menjadi lebih baik. Untuk mencapai tujuan tersebut, dilakukan kegiatan-kegiatan di lingkungan sekolah dan diluar sekolah untuk ditunjukan sebagai proses untuk memperkuat budipekerti siswa agar mempunyai karakter disiplin yang kuat serta mempunyai jiwa pancasila yang kuat. Melalui pendidikan pramuka akan menimbulkan rasa tolong menolong, tanggungjawab, serta punya kepribadian baik di sekolah maupun diluar sekolah. 
Seperti halnya menurut Gilang (2014) sesuai dengan Permendikbud Nomor 63 Tahun 2014 tentang kepramukaan sebagai ekstrakurikuler wajib disekolah itu adalah untuk dapat mengembangkan kemampuan dan membentuk watak serta peradaban bangsa yang bermartabat dalam rangka mencerdaskan kehidupan bangsa. Selain itu juga bertujuan untuk mengembangkan potensi peserta didik agar menjadi manusia yang beriman dan bertakwa kepada Tuhan Yang Maha Esa, berakhlak mulia,sehat, berilmu, cakap, kreatif, mandiri, disiplin, dan menjadi warga negara yang demokratis serta bertanggung jawab. Seperti yang ada dalam pasal inilah yang Seharusnya sudah ditanamkan kepada siswa agar lebih dapat menjadikan siswa lebih baik dalam perilaku siswa di sekolah. Selain itu juga karekter disiplin disekolah juga sangat diperlukan dalam kegiatan belajar di sekolah agar menunjang belajar yang baik. Salah satu upaya yang dilakukan diantranya yaitu mendayagunakan manajemen kesiswaan dengan sebaik-baiknya. Sejalan dengan hal itu, terdapat prinsip yang dikemukakan oleh Imron (2012) bawasanya segala bentuk kegiatan manajemen siswa berbasis sekolah haruslah mengemban misi pendidikan dan dalam rangka mendidik para siswa. Segala bentuk kegiatan, baik itu ringan, berat, disukai, atau tidak disukai oleh siswa haruslah diarahkan untuk mendidik siswa dan bukan untuk yang lainya.

Berdasarkan jabaran dari latar belakang diatas, memberikan ide bagi peneliti untuk mengkaji tentang pokok ekstrakurikuler pramuka terhadap tingkat kedisiplinan siswa. Peneliti ingin mengetahui seberapa tinggi tingkat kedisiplinan siswa dan seberapa tinggi pengeruh dengan kegiatan ekstrakurikuler yang ada di sekolah SMK Negeri se-Kota Malang. Alasan mengambil penelitian di SMK Negeri di Kota Malang karena SMK Negeri setelah lulus dari sekolah di fokuskan untuk masuk ke dalam dunia kerja. Dunia kerja saat ini tidak hanya membutuhkan skils yang mumpuni, namun juga kedisiplinan karyawan yang bekerja disana. Kedisiplinan sangatlah diperlukan dalam dunia kerja karena sangat mempengaruhi dalam menjalankan pekerjaan. Selain itu perbedaan dari penelitian lain karena, penelitian ini dalam lingkup yang sangat luas, yaitu menggunakan seluruh SMK Negeri se-Kota Malang dan dapat membuat penelitian ini lebih bagus dan menjadi lebih general karena mengambil lingkup bayak. Pada akhirnya dalam penelitian ini dapat mengetahui bagaimana bentuk perilaku disiplin yang diperoleh dari kegiatan pramuka yang ada di sekolah. Berdasarkan keinginan peneliti tersebut maka peneliti ingin melakukan penelitian dengan judul Hubungan Keikutsertaan Ekstrakurikuler Pramuka dengan Tingkat Kedisiplinan Siswa di SMK Negeri se-Kota Malang.

\section{METODE}

Penelitian ini menggunakan pendekatan kuantitatif dengan jenis penelitian kuantitaif deskriptifkorelasional. Penelitian kuantitaif deskriptif-korelasional bertujuan untuk mengetahui ada tidaknya hubungan antar variabel. Lokasi yang dipilih untuk melakukan penelitian adalah di SMK Negeri se-Kota Malang. SMK ini tersebar secara luas di Kota Malang. Populasi penelitian ini adalah siswa sebanyak 6701, kemudian untuk menemukan jumlah responden digunakan rumus Tabel Krejcie \& Morgan sehingga menemukan jumlah sampel sejumlah 364 siswa. Pembagian sampel TAS tiap sekolah dihitung dengan rumus proportional random sampling. Pengambilan data pada penelitian ini menggunakan instrumen penelitian berupa angket atau kuesioner. Untuk skala pengukuran yang digunakan pada angket menggunakan skala likert dengan empat alternatif jawaban antara lain SS (Sangat Setuju), S (Setuju), TS (Tidak Setuju), dan STS (Sangat Tidak Setuju). Dan kemudian responden memberi jawaban dengan memberi checklist $(\sqrt{ })$ pada salah satu alternatif jawaban sesuai dengan keadaan yang dirasakan responden. Analisis data yang digunakan terdiri dari: (1) analisis deskriptif, yakni dengan menentukan panjang kelas interval dan persentase dari masing-masing variabel, (2) uji prasyarat analisis berupa uji normalitas, uji linearitas, dan (3) uji hipotesis berupa uji korelasi product moment pearson, uji regresi.

\section{HASIL}

\section{Analisis Deskriftif Variabel Keikutsertaan Ekstrakurikuler Pramuka}

Deskripsi data variabel ekstrakurikuler pramuka di dapatkan dari angket yang diberikan kepada 364 responden. Angket untuk variabel ekstrakurikuler pramuka dijabarkan dalam 49 pernyataan, dengan 4 
alternatif pilihan jawaban. Sementara itu untuk kategori kelas, peneliti menggunakan kategori 3 kelas interval yang meliputi kategori rendah, sedang, tinggi. Pada variabel ekstrakurikuler pramuka nilai tertingginya $\geq 168$ dan nilai terendahnya 120 . Nilai mean dalam analisis ini sebesar 154,56 .

Tabel 1 Data Variabel Ekstrakurikuler Pramuka

\begin{tabular}{|c|c|c|c|c|c|}
\hline \multirow{2}{*}{$\frac{\text { No }}{1}$} & \multirow{2}{*}{$\frac{\text { Kriteria }}{\text { Rendah }}$} & \multicolumn{2}{|c|}{ Kelas Interval } & \multirow{2}{*}{$\begin{array}{c}\text { Frekuensi } \\
78\end{array}$} & \multirow{2}{*}{$\begin{array}{c}\text { Persentasi } \% \\
23 \%\end{array}$} \\
\hline & & 120 & 143 & & \\
\hline 2 & Sedang & 144 & 167 & 191 & $56 \%$ \\
\hline \multirow[t]{2}{*}{3} & Tinggi & $\geq 168$ & & 70 & $21 \%$ \\
\hline & Total & & & 339 & $100 \%$ \\
\hline
\end{tabular}

Berdasarkan Tabel 1 dapat diketahui bahwa hasil analisis ekstrakurikuler pramuka di SMK Negeri se- Kota Malang tergolong untuk kriteria rendah sebesar dengan kelas interval 120-143 dan frekuensi 78 serta persentase 23\%, tergolong sedang, dengan kelas interval 14-167 dan frekuensi 191 serta persentase sebesar 56\%, dan tergolong tinggi degan kelas interval 168-191dan frekuensi 70 serta persentase sebesar $21 \%$. Jadi kesimpulan yang dapat diambil adalah presentase tingkat ekstrakurikuler pramuka di SMK Negeri se-Kota Malang dengan mean154,56 tergolong sedang dengan besar 56\%. Untuk mendeskripsikan persentase dari hasil dapat dilihat pada Gambar 1.

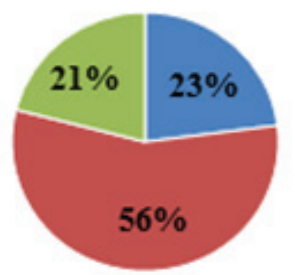

- RENDAH | SEDANG " TINGGI

Gambar 1 Diagram Variabel Ekstrakurikuler Pramuka

\section{Analisis Deskriftif Variabel Tingkat Kedisiplinan Siswa}

Deskripsi data variabel kedisiplinan siswa diperoleh dari angket yang dibagikan kepada 364 responden. Angket variabel kedisiplinan siswa terdiri dari 19 pernyataan dengan 4 alternatif jawaban. Sementara itu, untuk kategori kelas, peneliti menggunakan 3 kategori yang meliputi tinggi, sedang, dan rendah.

Tabel 2 Data Frekuensi Variabel Tingkat Kedisiplinan

\begin{tabular}{|c|c|c|c|c|c|c|}
\hline \multirow{2}{*}{$\frac{\text { No }}{1}$} & \multirow{2}{*}{$\begin{array}{c}\text { Kriteria } \\
\text { Rendah }\end{array}$} & \multicolumn{3}{|c|}{ Kelas Interval } & \multirow{2}{*}{$\begin{array}{c}\text { Frekuensi } \\
23\end{array}$} & \multirow{2}{*}{$\begin{array}{c}\text { Persentase } \% \\
\mathbf{7 \%}\end{array}$} \\
\hline & & 42 & - & 54 & & \\
\hline 2 & Sedang & 55 & - & 66 & 171 & $\mathbf{5 0} \%$ \\
\hline \multirow[t]{2}{*}{3} & Tinggi & $\geq 67$ & & & 145 & $43 \%$ \\
\hline & Total & & & & 339 & $100 \%$ \\
\hline
\end{tabular}

Berdasarkan Tabel 2 dapat diketahui bahwa hasil analisis ekstrakurikuler pramuka di SMK Negeri seKota Malang tergolong untuk kriteria rendah sebesar dengan kelas interval 42-54 dan frekuensi 23 serta persentase 7\%, tergolong sedang, dengan kelas interval 55-66 dan frekuensi 171 serta persentase sebesar $50 \%$, dan tergolong tinggi degan kelas interval 67-79dan frekuensi 145 serta persentase sebesar $43 \%$. Jadi kesimpulan yang dapat diambil adalah presentase tingkat ekstrakurikuler pramuka di SMK Negeri se-Kota Malang dengan mean154,56 tergolong sedang dengan besar 50\%. Untuk mendeskripsikan persentase dari hasil dapat dilihat pada Gambar 2. 


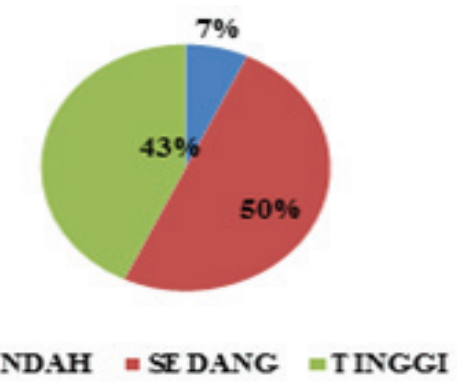

Gambar 2 Diagram Variabel Tingkat Kedisiplinan

\section{Uji Normalitas}

Sebelum dilakukan analisis untuk uji coba hipotesis, data lebih dahulu diuji dengan uji normalitas, uji normalitas sendiri dimaksudkan untuk mengatasi apakah suatu set data berdistribusi normal atau tidak. Dalam penelitin ini peguji menggunakan uji normalistas Kolmogorov Smirnov. Uji normalitas dikatakan normal apabila nilai signifikansi dari uji normalitas memiliki nilai lebih dari 0,05 $(\mathrm{p}>0,05)$. Dan sebaliknya dikatakan tidak normal apabila nilai signifikansi dari uji memiliki nilai kurang dari $0,05(\mathrm{p}<0,05)$. Untuk uji normalitas ini, peneliti menggunakan program SPSS versi 20.0. hasil uji normalitas akan bisa dilhat pada Tabel 3 .

Tabel 3 Uji Normalitas Kolmogorov Smirnov

One-Sampel Kolmogorov-Smirnov Test

\begin{tabular}{llcc}
\hline & & Eks Pramuka & Kedisiplinan Siswa \\
\hline N & & 339 & 339 \\
Normal Parameters ${ }^{\mathrm{a}, \mathrm{b}}$ & Mean & $\mathbf{1 5 4 . 5 6}$ & $\mathbf{6 5 . 2 4}$ \\
& Std. Deviation & $\mathbf{1 4 . 8 6 4}$ & 7.487 \\
Most Extreme & Absolute & .048 & .047 \\
Differences & Positive & .048 & .047 \\
& Negative & -.028 & $\mathbf{. 0 4 4}$ \\
Test Statistic & & .048 & .047 \\
Asymp. Sig. (2-tailed) & & $.054^{\mathrm{c}}$ & $.064^{\mathrm{c}}$ \\
\hline
\end{tabular}

Berdasarkan Tabel 3 didapatkan perhiitungan nilai signifikan masing-masing variabel, yang meliputi variabel ekstrakurikuler pramuka 0,054, dan variabel tingkat kedisiplinan. Sudah disebutkan diatas bahwa data dikatakan normal apabila nilai signifikan dari uji normalitas memiliki nilai lebih dari $0,05(\mathrm{p}>0,05)$. Dan sebaliknya dikatakan tidak normal apabila nilai signifikan daru uji memiliki kurang dari $0,05(\mathrm{p}<0,05)$. Variabel ekstrakurikuler pramuka memiliki nilai signifikan $0,054>0,05$. Maka data variabel ekstrakurikuler pramuka berdistribusi normal. Variabel tingkat kedisiplinan memiliki nilai signifikan $0,064>0,05$, maka data variabel tingkat kedisiplinan berdistribusi normal. Maka dari ini dapat disimpulakn bahwa semua data di setiap variabel berdistribusi normal.

\section{Uji Linearitas}

Uji linearitas digunakan untuk mengetahui apakah hubungan antara variabel linier atau tidak. Uji linearitas nisa dilakukan melalui pengujian hasil signifikan uji lenearitas dengan taraf signifikan $a$ $(0,05$. Dasar pengambilan keputusannya yakni apabila nilai $\operatorname{Sig}>a(0,05)$ maka hubungan linier, atau dengan Deviation from Linearity, jika Fhitung $<$ F tabel maka hubungan linear. Untuk hasil perhitungan dari uji linearitas dengan menggunakan SPSS versi 20.0 dapat dilihat pada Tabel 4. 
Tabel 4 Hasil Uji Linieritas ANOVA (Eks Pramuka)

\begin{tabular}{|c|c|c|c|c|c|c|c|}
\hline & & & $\begin{array}{l}\text { Sum of } \\
\text { Squares }\end{array}$ & Df & Mean Square & $\mathbf{F}$ & Sig. \\
\hline \multirow{4}{*}{$\begin{array}{l}\text { Kedisiplinan Siswa * } \\
\text { Eks Pramuka }\end{array}$} & \multirow[t]{3}{*}{ Between Groups } & (Combined) & 7282.232 & 62 & 117.455 & 2.779 & .000 \\
\hline & & Linearity & 4706.719 & 1 & 4706.719 & & .000 \\
\hline & & $\begin{array}{l}\text { Deviation from } \\
\text { Linearity }\end{array}$ & 2575.512 & 61 & 42.222 & .999 & .485 \\
\hline & \multicolumn{2}{|l|}{ Within Groups } & 11666.447 & 276 & 42.270 & & \\
\hline Total & & & 18948.678 & 338 & & & \\
\hline
\end{tabular}

Dari Tabel 4 diperoleh hasil analisis nilai signifikan Deviation from Linearity untuk variabel ekstrakurikuler pramuka sebesar 0,485. Hasil signifikan 0,485 lebih besar dari $0,05(0,485>0,05)$ sehingga dapat diartikan bahwa variabel ekstrakurikuler pramuka terdapat hubungan dengan tingkat kedisiplinan siswa yang linier.

\section{Uji Hipotesis}

Penelitian ini bertujuan untuk mengetahui hubungan antara ekstrakurikuler pramuka dengan tingkat kedisiplinan siswa di SMK Negeri se-Kota Malang. Dalam penelitian ini untuk mengetahui hubungan tersebut yakni menggunakan rumus analisis korelasi Product Moment Pearson dengan program SPSS versi 20.0. Tingkatan uji korelasi bisa dilihat pada Tabel 5.

Tabel 5 Hasil Analisis Korelasi Variabael X dan Y

\begin{tabular}{llll}
\hline & & Eks Pramuka & Kedisiplinan Siswa \\
\hline Eks Pramuka & Pearson Correlation & $\mathbf{1}$ & $\mathbf{. 4 9 8}^{* *}$ \\
& Sig. (2-tailed) & & $\mathbf{. 0 0 0}$ \\
& $N$ & $\mathbf{3 3 9}$ & $\mathbf{3 3 9}$ \\
Kedisiplinan Siswa & Pearson Correlation & $\mathbf{. 4 9 8}$ & $\mathbf{1}$ \\
& Sig. (2-tailed) & $\mathbf{. 0 0 0}$ & \\
Total & & $\mathbf{3 3 9}$ & $\mathbf{3 3 9}$ \\
\hline
\end{tabular}

Berdasarkan hasil diatas diketahui nilai signifikan sebesar 0,000 dan nilai Pearson Correlation sebesar 0,498. Maka nilai signifikan 0,000 lebih kecil dari $0,005(0,000<0,05)$ maka H0 ditolak dan H1 diterima, sehingga dapat diartikan bahwa terdapat hubungan antar variabel ekstrakurikuler pramuka dengan tingkat kedisiplinan, dan kedua variabel tersebut memiliki hubungan yang positif karena nilai Pearson Correlation bernilai positif. Dengan nilai Pearson Correlation sebesar 0,498 dan di cocokan dengan Table 6 maka kedua variabel memiliki hubungan yang sedang/ cukup.

Tabel 6 Tingkat Uji Korelasi

\begin{tabular}{cc}
\hline Nilai Korelasi & Keterangan Tingkatan \\
\hline $\mathbf{0 , 0 0}-\mathbf{0 , 2 5}$ & Lemah \\
$\mathbf{0 , 2 6}-\mathbf{0 , 5 0}$ & Sedang/Cukup \\
$\mathbf{0 , 5 1}-\mathbf{0 , 7 5}$ & Kuat \\
$\mathbf{0 , 7 6}-\mathbf{0 , 9 9}$ & Sangat kuat \\
1,00 & Sempurna \\
\hline
\end{tabular}

\section{PEMBAHASAN}

\section{Keikutsertaan Ekstrakurikuler Pramuka}

Diketahui bahwa hasil analisis deskriptif diketahui bahwa keikutsertaan ekstrakurikuler pramuka di SMK Negeri se-Kota Malang tergolong dalam kategori sedang. Hasil penelitian tersebut mengindikasikan bahwa penerapan kegiatan pramuka dan dasa darma pramuka sudah sudah terlaksana dengan cukup baik di sekolah. Pelaksanaan kegiatan pramuka di sekolah dalam kurikulum 2013 sekarang ini sudah diwajibkan 
siswa untuk mengikutinya. Seperti halnya menurut Gilang (2014) seuai dengan Permendikbud Nomor 63 Tahun 2014 Kepramukaan sebagai Ekstrakurikuler Wajib yang ada dalam sekolah adalah bertujuan untuk mengembangkan kemampuan dan membentuk watak serta peradaban bangsa yang bermartabat dalam rangka mencerdaskan kehidupan bangsa. Maka dari itu dengan palaksanaan ekstrakurikuler pramuka di SMK Negeri se-Kota Malang dengan kategori cukup baik maka dapat mendorong sekolah dalam mencapain tujuan seperti halnya membentuk watak siswa dan mengembangkan kemampuan siswa agar lebih baik lagi.

Hasil analisis deskriftif ekstrakurikuler pramuka didukung dengan penelitian terdahulu oleh Alam (2017) menjelaskan bahwa kegiatan pramuka di SMK Negeri 2 Wonosari mendapatkan kategori cukup baik. Selain itu penelitian lain yang yang membahas mengenai ekstrakurikuler pramuka dilakukan oleh Saraswati (2017) yang mendapatkan hasil sanggat tinggi, hal ini dikarenakan penelitian yang dilakukan di SMP Negeri 1 Banasari tingkatan partisipasi ekstrakurikuler kategori tinggi karena siswa mengikuti pelatihan kepramukaan minimal satu minggu sekali, mengikuti berbagai macam perlombaan serta mengikuti berbagai macam pelatihan yang membentuk keterampilan sosial siswa.

Maka dapat dikatakan penelitain Alam dan Saraswati ini mendukung penelitian ini, karena dengan bentuk kegiatan-kegiaatan itu bentuk partsisipasi siswa menjadi mengikuti kegiatan ekstrakurikuler pramuka dalam kategori sedang, namun ada perbedaan dalam penelitian ini dengan penelitian terdahulu. Perbedaan ini terdapat pada jumlah populasi penelitian. Dalam penelitian ini menggunakan populasi seluruh Kota Malang, sedangkan penelitian terdahulu hanya fokus terhadap satu sekolah. Hasil dari penelitian ini juga mengemukakan hasil yang lebih tinggi yaitu 56\%, sedangkan penelitian oleh Alam mendapatkan hasil 31\% sedangkan penelitian yang dilakukan oleh Saraswati mendapatkan hasil yang lebih tinggi dengan $76 \%$

\section{Tingkat Kedisipinan Siswa}

Kedisiplinan siswa adalah bentuk keadaan tertib yang ada di dalam sekolah. Kedisiplinan sangatlah memberikan pengaruh yang baik dalam memperlancar kegiatan belajar di sekolah. Tanpa adanya kedisiplinan dan pengaruh peilaku disiplin siswa disekolah tentunya pasti berprilaku seenaknya sendiri. Dalam hal ini sesuai pendapat yang di kemukakan oleh Imron (2012) kedisiplinan adalah suatu keadaan tertib dan teratur yang dimiliki oleh peserta didik di sekolah, tanpa ada pelanggaran-pelanggaran yang merugikan baik secara langsung maupun tidak langsung terhadap peserta didik dan terhadap sekolah secara keseluruhan.

Diketahui bahwa hasil analisis deskriftif yang sudah dilakukan, dapat diketahui bahwa tingkat kedisiplinan siswa berada pada ketegori sedang. Ketegori sedang ini menyatakan bahwa kedisiplinan siswa di SMK Negeri Malang masih cukup baik, hal ini dapat diartikan bahwa disiplin belajar dan pembinaan belajar dilaksanakan dengan cukup baik. Sehingga siswa dapat menjadi lebih disiplin dalam berperilaku sehari-hari baik di sekolah maupun di luar sekolah. Hal ini di dukung oleh pernyataan Indrakusuma (2002) yaitu tujuan disiplin untuk menanmkan atau membiasakan bersikap disiplin baik di sekolah maupun di luar sekolah dan pada akhirnya disiplin tumbuh dari hati sanubari.

Sesuai dengan penelitian yang dilakukan oleh Alam (2017) yang melakukan penelitian di SMK Negeri 2 Wonosari yang mengemukakan hasil tingkat kedisiplinan berkategori cukup baik. Penelitian lain yang membahas mengenai tingkat kedisiplinan adalah penelitian yang dilakukan oleh Lestari (2011) yang mendapatkan hasil bahwa tingkat kedisiplinan berada pada kategori sedang. Sama dengan penelitian ini yang mendapatkan hasil sedang, hal ini dikarenakan dari tingkat kedisiplinan atau perilaku siswa yang kurang baik. Hasil ini sudah dapat dikatakan cukup baik/sedang, tapi pastinya jika sekolah mengusahakan perilaku disiplin kepada siswa untuk lebih berperilaku dengan disiplin, maka sekolah bisa mendapatkan hasil tingkat kedisiplinan yang sangat baik.

\section{Hubungan Keikutsertaan Ekstrakurikuler Pramuka dengan Tingkat Kedisiplinan Siswa}

Sesuai dengan hasil penelitian yang telah dipaparkan pada bab IV dijelaskan bahwa dari hasil analisis perhitungan menggunakan software SPSS Statistics bahwa keikutsertaan ekstrakurikuler pramuka mimiliki hubungan dengan tingkat kedisiplinan siswa di SMK Negeri se Kota Malang. Hubungan yang 
bersifat positif ini dimaksudkan bahwa diantara dua variabel penelitian tersebut berjalan searah yang berarti jika variabel ekstrakurikuler pramuka mengalami kenaikan maka variabel tingkat kedisiplinan siswa juga akan mengalami kenaikan. Semakin tinggi keikutsertaan siswa dalam mengikuti kegiatan pramuka maka tingkat kedisiplinan siswa juga akan lebih baik.

Adanya hubungan ekstrakurikuler pramuka dengan tingkat kedisiplinan siswa didukung oleh pendapat Fitri (2012) mengemukakan bahwa kegiatan pramuka, siswa dapat dilatih dan dibina untuk mengembangkan diri dan meningkatkan hampir semua betuk karakter. Misalnya dalam melatih karakter kedisiplinan, jujur, menghargai waktu, tertib, tanggungjawab. Selain itu untuk lebih lebih tepatnya semua nilai yang terkandung dalam dasa darma pramuka. Selain itu, Seperti halnya menurut Gilang (2014) seuai dengan Permendikbud Nomor 63 Tahun 2014 Tentang Kepramukaan sebagai Ekstrakurikuler Wajib bertujuan untuk mengembangkan potensi peserta didik agar menjadi manusia yang beriman dan bertakwa kepada Tuhan Yang Maha Esa, menjadikan watak yang baik, berakhlak mulia,sehat, berilmu, cakap, kreatif, mandiri, disiplin. Pendapat lain berasal dari Hudiyono (2012) menyatakan hal sebagai berikut seperti, yaitu berupa pembinaan watak yang di dalamnya ada disiplin, budi pekerti yang baik, jujur, patuh, tekun, selain itu dapat membentuk mental, emosional, jasmani, dan bakat, serta meningkatkan iman dan taqwa.

Penelitian-penelitian lain yang telah dilakukan sebelum penelitian ini seperti penelitian yang dilakukan oleh Suryani (2017) juga menyatakan bahwa antara ekstrakurikuler pramuka dengan tingkat kedisiplinan siswa di SMP Negeri 1 Terusan Nunyai terdapat hubungan positif. Hal ini mengartikan bahwa kegiatan pramuka yang baik dan lancar akan berbanding lurus dengan tingkat kedisiplinan siswa di sekolah. Namun jika kegiatan pramuka mengalami penurunan, maka tingkat kedisiplinan siswa juga dapat mengalami penurunan juga. Penelitian lain oleh Kurniawan (2017) Hasil dan pembahasan dapat disimpulkan bahwa terdapat terdapat hubungan yang positif dan signifikan antara ekstrakurikuler kepramukaan dan kedisiplinan kelas III SDN Gugus Ki Hajar Dewantara Kecamatan Mijen Kota Semarang. Penelitian lain yang membahas mengenai ekstrakurikuler pramuka dengan tingkat kedisiplinan adalah Dahira (2017) yang dimana hasilnya menunjukan bahwa tingkat kedisiplinan siswa di SD Negeri 10 Banda Aceh tergolong dalam memiliki hubungan yang positif dengan ekstrakurikuler pramuka. Hal ini menunjukan bahwa siswa SD sudah dibekali kegiatan pramuka untuk memupuk perilaku disiplin sejak dini. Sehingga jika kegiatan pramuka semakin aktif maka tingkat kedisiplinan siswa juga akan mengalami kenaikan pula. Dari hasil positif baik antara penelitian ini dan penelitian terdahulu membuat kegiatan pramuka ini begitu penting karena setiap siswa yang mengikuti esktrakulikuler pramuka di sekolah akan mendapatkan pengalaman dan pendidikan karakter sebagai pembentuk watak yang baik.

\section{SIMPULAN DAN SARAN}

\section{Simpulan}

Berdasarkan hasil penelitian dan pembahasan yang telah dipaparkan, maka dapat ditarik kesimpulan sebagai berikut: (1) tingkat keikutsertaan pramuka di SMK Negeri se-Kota Malang berada pada kategori sedang. Hasil sedang ini dapat dikatakan ekstrakurikuler pramuka sudah berjalan dengan cukup baik, namun masih kurang maksimal. Hal ini dikarenakan siswa kurang tertarik dengan adanya ekstrakurikuler pramuka, sehingga dengan diwajibkannya ekstrakurikuler pramuka di sekolah membuat siswa kurang ikhlas dalam mengikutinya. (2) tingkat kedisiplinan siswa SMK Negeri se Kota Malang berada pada kategori sedang. hasil sedang ini dapat dikatakan ekstrakurikuler pramuka sudah berjalan dengan cukup baik, namun masih kurang maksimal. hal ini dikarenakan siswa kurang menanamkan dan membiasakan bersikap disiplin baik di sekolah maupun di luar sekolah. (3) hasil penelitian ini menunjukkan adanya hubungan positif yang signifikan antara ekstrakurikuler pramuka dengan tingkat kedisiplinan siswa SMK Negeri se-Kota Malang. Hasil yang mengemukakan bahwa antar variabel memiliki hubungan karena, adanya pengaruh kegiatan ekstrakurikuler pramuka di sekolah yang diikuti oleh siswa sehingga perilaju disiplin akhirnya tertanam di dalam diri siswa. 


\section{Saran}

Saran ditujukan kepada (1) kepala sekolah yaitu, untuk mempermudah jika ada penelitian lain yang akan penelitian mengenai ekstrakurikuler pramuka dan tingkat kedisiplinan siswa dengan prestasi belajar. Mengenai prestasi belajar itu sangatlah penting karena lebih memfokuskan hasil nilai siswa, jadi sekolah dapat mengetahui bentuk prestasi siswa yang dihasilkan setelah mengikuti esktrakurikuler pramuka. Selain itu kepala sekolah sebagai penanggungjawab utama haruslah memberikan arahan kepada Bapak/Ibu guru untuk selalu menerapkan perilaku disiplin di sekolah, agar siswa juga meneladani pengaruh perilaku dari perilaku tersebut, (2) waka kesiswaan sekolah juga mempunyai peran untuk membuat siswa menjadi lebih disiplin. Saran untuk Waka Kesiswaan di sekolah agar lebih memberikan didikan kepada siswa di sekolah selain melalui kegiatan pramuka juga dengan tat tertib yang dibuat oleh kesiswaan. Dengan demikian peraturan sekolah tersebut hasrusnya dipatuhi dan juga harus dijalankan. Waka Kesiswaan juga harus membuat jera siswa yang selalu mengulangi pelanggaran di sekolah dengan memnghukum atau memberi peringatan kepada siswa. (3) wali murid siswa untuk selalu memberikan dukungannya disiplin yang kuat, karena dukungan dari luar sekolah sangat diperlukan untuk membatasi perilaku siswa agar tidak seenaknya sendiri. Wali murid mempunyai hak yang sangat penting di luar sekolah karena pengaruh yang paling banyak mengenai hal baik mapun buruk pastinya dari luar sekolah. Jadi orangtua siswa harus lebih mengawasi siswa agar selalu terpantau perilakunya. (4) peneliti lain hendaknya dapat mengembangkan penelitian ini, yaitu dengan memperbaiki kekurangan yang ada dalam penelitian ini dengan mencari pemecahan masalah yang ada dalam kedisiplinan siswa di sekolah. Selain itu juga peneliti lain juga dapat menambahkan variabel lain di bagian akhir seperti prestasi belajar siswa. Prestasi belajar sangat disarankan untuk melengkapi penelitian ini dikarenakan prestasi belajar merupakan hasil akhir dari proses kegiatan belajar siswa di sekolah.

\section{DAFTAR RUJUKAN}

Alam, D.R. 2017. Pengaruh Kegiatan Ekstrakurikuler Pramuka Terhadap Kedisiplinan Siswa Kelas Xi Jurusan Teknik Gambar Bangunan Di Smk Negeri 2 Wonosari. Jurnal Pendidikan Teknik Sipil dan Perencanaan Tahun 2017. Dari http://journal.student.uny.ac.id/ojs/ojs/index.php

Dahira, S. 2017. Pengaruh Kegiatan Ekstrakurikuler Pramuka Dalam Kurikulum 2013 Terhadap Kedisiplinan Siswa Kelas V Di Sd Negeri 10 Banda Aceh. Jurnal Ilmiah Pendidikan Guru Sekolah Dasar FKIP Unsiyah Volume 2 Nomor 2, 92-102. Dari http://www.jim.unsyiah.ac.id/pgsd/article/view/4570.

Fitri, A.Z. 2012. Pendidikan Karakter Berbasis Sekolah \&Etika Sekolah. Yogyakarta: Ar-Ruzz Media.

Gilang, 2014. Permendikbud Nomor 63 Tahun 2014 Tentang Kepramukaan sebagai Ekstrakurikuler Wajib. (Online), (https://www.slideshare.net/gilangasridevianty/lampiran-i-permen-nomor-63-th-2014). Diakses pada 12 Februari 2019.

Hudiyono. 2012. Membangun Karakter Siswa: Melalui Profesionalisme Guru dan Gerakan Pramuka. Jakarta: Esansi Erlanga Group.

Imron, A. 2012. Manajemen Peserta Didik Berbasis Sekolah. Jakarta: Bumi Aksara.

Indrakusuma, A.D. 2002. Pengantar Ilmu Pendidikan. Surabya: Usaha Nasional.

Kurniawan, R.A. 2017. Hubungan Ekstrakurikuler Kepramukaan Dan Kedisiplinan Dengan Hasil Belajar Pendidikan Kewarganegaraan Siswa Kelas III SDN Kecamatan Mijen Kota Semarang. (Online). (http://lib. unnes.ac.id/31230/1/1401413038.pdf). Diakses pada 13 Maret 2019.

Lestari, W. L. 2011. Upaya Meningkatkan Kedisiplinan Siswa Dalam Menaati Tata Tertib Melalui Layanan Penguasaan Konten Dengan Teknik Modelling Pada Siswa Kelas Vii Smp Negeri 11 Semarang. (Online), (https://lib.unnes.ac.id/10109/1/6475.pdf). Diakses pada 26 Juni 2019.

Saraswati, R.E. 2017. Hubungan Partisipasi Ekstrakurikuler Pramuka dengan Kterampilan Sosial di SMPN 1 Banasari. 233 Jurnal Riset Mahsiswa Bimbingan dan Konseling, Volume 3, 6 Juni 2017. http://journal. student.uny.ac.id/ojs/index.php/fipbk/article/viewFile/7650/7284.

Suryani. P. Pengaruh Kegiatan Pramuka Terhadap Kedisiplinan Siswa Kelas VIII SMP Negeri 1 Terusan Nunyai. (Online), (Http://Digilib.Unila.Ac.Id/29031/3/Skripsi\%20tanpa\%20bab\%20pembahasan.Pdf). Diakses pada 12 Februari 2019). 